\title{
Social and Demographic Conditions of Displays of Aggression and Violence in Family
}

\author{
Małgorzata Przybysz-Zaremba ${ }^{1}$, Agata Katkoniené ${ }^{2}$ \\ 1 Department of Pedagogy Aleksander Gieysztor Academy of Humanities in Pułtusk (Poland), 36B Mickiewicza St., \\ 06-100 Pułtusk, malgorzata.p_z@interia.pl \\ 2 Institute of Educational Sciences and Social Work Faculty of Social Technologies Mykolas Romeris University \\ (Lithuania), Ateities St. 20, LT-08303 Vilnius, Lithuania, agata.katkoniene@mruni.eu
}

\begin{abstract}
The purpose of the research was to discover some selected social and demographic factors which can influence the displays of aggression and violence as well as the alcohol abuse. Several factors were taken into analysis: men's age, their education, place of residence and the jobs which they perform. The analysis of the research results confirmed that displaying aggression and / or violence is strictly related to abusing alcohol. The research indicated that aggression and violence happen most frequently in families in which the men's age is between 23 to 30 ; it happens with men with higher and secondary education who are regular alcohol drinkers; most often in the rural area.
\end{abstract}

Keywords: aggression, violence, alcohol abuse, family.

\section{To introduce: aggression and violence in family - explication of terms}

Aggression and violence happening in family is not a new phenomenon in society. More and more frequently this phenomenon is becoming a part of everyday life, the one we have got accustomed to, the one we have learnt to live with.

In the literature, the terms aggression and violence are treated ambiguously, thus they are difficult to define properly. The terms are related, describing the same mental states and behaviours, however, they do differ in terms of causes, results as well as the range of 
negative behaviours. P. G. Zimbardo and R. J. Gerrin (2011) perceive aggression as 'purposeful and aware physical or verbal behaviour undertaken against somebody or something and whose purpose is to cause injury or destruction'. A. Lipowska-Teutsch (quotation after: Mazur, 2002), however, treats violence as 'a sequence of behaviour of intentional and instrumental character and whose purpose is to enslave a victim, to eliminate their sovereign thoughts and actions and to subordinate the victim to the perpetrator's demands and needs'.

There is a definite difference between these terms, which is: a characteristic feature of aggressive behaviour is the balance of physical or mental power between the participants, whereas in violence there is the power imbalance (Przybysz-Zaremba, 2013) Aggression often has a reactive character, it is a reaction against stimuli of various kinds, while violence is characterised with four criteria, which are: intentionality, asymmetry of powers, violation of rights as well as suffering and caused damages (Jaszczak-Kuźmińska, Michalska, 2010).

Therefore, in family we deal with violence frequently called domestic or family violence ${ }^{1}$. It may refer to each family member (Więckiewicz, 2013) but it is the most often an action which is intentional and directed at taking advantage of the weaker family members (i.e. wife or children.) (Sasal, 1998), although it repeatedly faces the acts of aggression.

Aggression and violence happening in family may have various forms and take place through various instruments. Family members living under the same roof with an aggressor also abusing alcohol experience physical, mental or sexual violence and more frequently economic violence.

\section{Conditioning of aggression and violence in family}

Both in the Polish literature (Mellibruda, 2005; Mazur, 2002; Pospiszyl, 1994) and the English one (Blackman, 1989; Irons, Schneider, 1997; Kelder, McNamara, Carlson, Lynn, 1991) we can find numerous research confirming that the basic determinant triggering the aggressive or violent behaviour is alcohol. The analysis of sociological research indicate that we learn violence by witnessing it or experiencing it in life (Kaufman, 1994) Men learn that violence is one of the forms of relations between the sexes. The research conducted by M.S. Kimmel (2000) displays that 'the violence of husbands against their wives does not depend on the level of education, social class or man's ethnic background.

\footnotetext{
${ }^{1}$ According to the law of 29. July, 2005 on counteracting against the violence in family (J.o.L. of 2010, no. 125 , pos. 842) domestic violence is to be understood as single or repeated purposeful action or negligence violating laws or personal possessions of people [defined in art. 2 p.2 of aforementioned law - family member is to be understood as any closest person in the meaning of art. $115 \$ 11$ of law of 06 June, 1997. Penal Code (J.o.L. no. 88, pos. 553 with late amendments), as well as any other person co-habiting], especially endangering such persons to the loss of life, health, violating their dignity, bodily integrity, freedom, including sexual freedom, causing any damages in their physical or mental life as well as causing torment moral harm with people suffering from violence.'
} 
Boys' aggression against girls is definitely more frequent than girls' aggression against boys. Violence is institutionalised socially, economically and politically. It is more or less accepted, even if it deserves to be condemned (war, rape, assault, cursing, mental violence) (Arcimowicz, 2005). That is why to some extent it is allowed for, for example, in family.

Among the demographic factors having a huge influence on displaying aggression or violence, among others, there are man's young age or low income (Makara-Studzińska, Grzywa, Turek, 2005; Więckiewicz, 2012). According to WHO (2002) the factors related to the risk of using aggression or violence against a woman-partner are, among others: individual factors, factors related to the relationship, environmental factors and social ones. The scheme below presents it with details (Fig.).

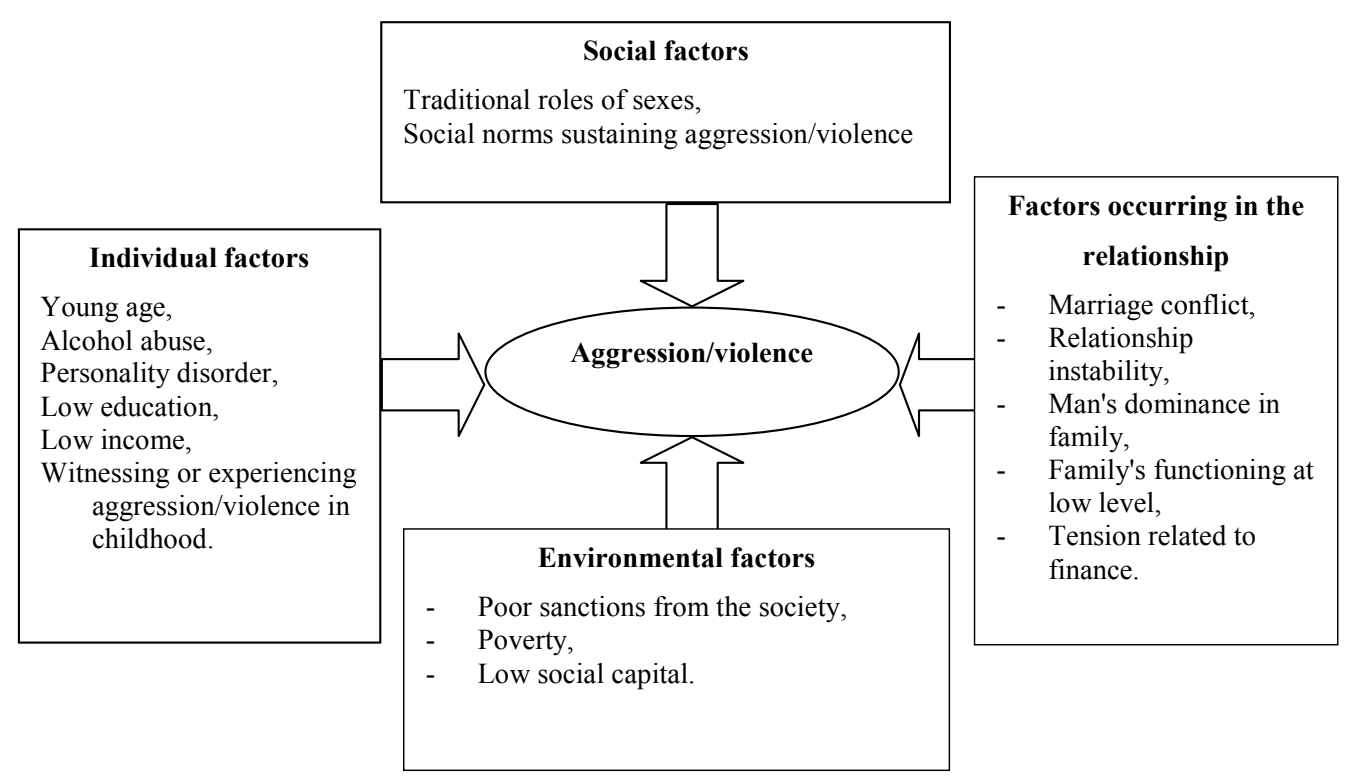

Fig. Conditioning of aggression and violence in family Source: author on the basis of: Makara-Studzińska et al., 2005, p. 133

The presented scheme including the factors of risk of using aggression and violence jest a general outline of most frequent risk factors, thus, it is not fully complete. In the methodological part of this work the author presents selected social and demographic conditions of aggressive-violent behaviours presented by men. The research relates to such (variable) factors as: men's age, their education, place of residence and the job they perform. While the present aggression or violence is closely related to the alcohol abuse (confirmed in many research), the author attempts at indicating whether the selected variables in the research also influence the men's reaching for alcohol pointing out at the same time the conditioning of aggressive-violent behaviours under its influence. 


\section{Research methodological assumptions}

The purpose of the research was to acknowledge the selected social and demographic conditions which can influence the displays of aggression and violence as well as alcohol abuse. Several factors were taken into analysis: men's age, their education, place of residence and the job which they perform.

The following research problems were identified:

1. Is there a relation between men's age, their education and place of residence and the aggression and / or violence happening in family?

2. Does the job they perform influence the displays of aggression and / or violence?

3. Is there any relation between men's age, their education, the place of their residence and the alcohol abuse?

4. Is there a relation between the type of the job the men perform and the alcohol abuse?

The research was conducted among 710 women $^{2}$ staying in relationship (the relationship was not always legalised) with children and experiencing on bigger or smaller scale aggression and / or violence from their partner / husband. The sampled group generally came from rural areas with population slightly higher than 500 people $(81.7 \%)$. Only $18.3 \%$ of the women came from towns with the population not exceeding 5,000 people. The survey research was conducted among the women of Warmian-Masurian Province and Pomeranian Province. To develop the data the elements of statistics analysis were used. Chi-squared test $\left(\mathrm{Chi}^{2}\right)$ and $\mathrm{V}_{\mathrm{xy}}$ - Cramer coefficient were used.

\section{Research result analysis}

The statistics analysis indicated that the assumed in the research relation between men's age, their education, their place of residence and the type of the job they perform versus the displays of the aggressive behaviours and / or violent behaviours ${ }^{3}$ was not fully confirmed. The research pointed out that the type of the job the men perform does not have a significant influence on the displays of aggression and / or violence. The assumed in statistical analysis null hypothesis fully confirmed the lack of such a relation $\left(\mathrm{Chi}^{2}{ }_{\text {emp. }}\right.$

\footnotetext{
2 Since the issue was related to men's aggression and violence the research was conducted among their wives / partners. It was considered that the results would be more credible. The problem of aggression and violence which to bigger or smaller extend was experienced by women and their children is a very delicate personal issue, therefore in-depth analysis of the kinds of aggression, violence and analysis of the situations during which such behaviours happen were given up. The women were reluctant to provide some extended information on this issue

3 In this work the author uses the term aggression and/or violence since the sampled women did not define in details whether their family experiences aggression or violence. Literature, however, underlines that there are differences in definitions of aggression and violence.
} 
$5.83<\mathrm{Chi}_{\text {tab. }}^{2}$ 7.78, $\mathrm{df}=2, \mathrm{a}=0.05, \mathrm{~V}$-Cramer coefficient $\left.=0.091\right)$. The rest of the assumed variables were confirmed also with relation to alcohol abuse.

Men's age and the aggressive behaviours and / or violent behaviours as well as the alcohol abuse in family

The statistical analysis indicated the relation between men's age and the aggressive behaviours and/or the violent behaviours. The achieved data was following: $\mathrm{Chi}^{2}{ }_{\text {emp. }}$. $65.43>\mathrm{Chi}^{2}{ }_{\text {tab. }}$.7.78, $\mathrm{df}=3, \mathrm{a}=0.05, \mathrm{~V}$-Cramer coefficient $=0.304$.

As it results from the data included in fig. 1, the aggressive behaviours and / or violent behaviours take place most often in the sampled families in which the men are in the age group between 23 and 30 years of age. The indicator for this particular group of men is the highest and it is $55.8 \%$. Although the sampled women were not willing to refer type of aggression / violence or the situation during which such behaviours did happen most often, it can be assumed that it happened. The men (and also the women) being 23 years old and deciding to start a family do not necessarily have to be fully prepared for the role of father, life partner and protector. Some situations related to the fulfilment of such roles could simply be 'far beyond' or even the tasks and duties related to the chosen roles could have been transferred to women - especially in situations when a child / children appear in family. Men of this age, as it can be observed socially, need some time in order to so called 'cut loose', 'party wild', the time during which they use the best of their time without any obstacles. Starting a family at such young age brings the men some duties, tasks, roles which they do not always accept consciously and sometimes it turns out that they are simply made to accept some roles, for example due to unwanted pregnancy.

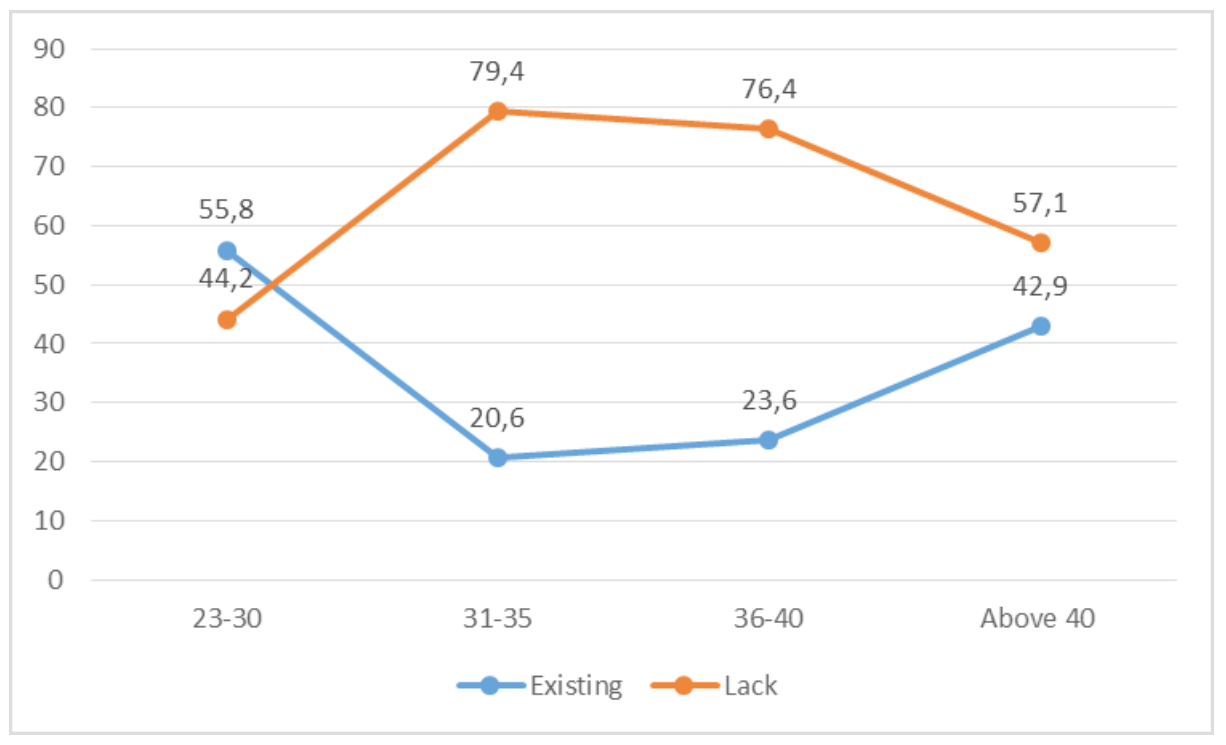

Fig. 1. Men's age and aggression / violence in family (in \%)

Source: author's own based on the conducted research 
Aggressive behaviours and / or violent behaviours are also more frequent in families in which the men are over their 40 years of age $(42.9 \%$.) The justification of the data can be the fact that such group of men have reached certain level of education, is being realised professionally (it also includes women), the children are adult enough to take care of themselves. The professional activeness, which at present is often related to shaping the professional career leading to reaching certain levels of promotion which more and more often is associated with experiencing some risk situations at work, can cause a situation in which some problems are transferred on the family ground. Men fail to stand some stressful situations, which probably leads 'to take it out' on their family. Displaying the aggressive and/or violent behaviours of men against the other family members can be related to the abuse of alcohol as it is confirmed by numerous research (Burek, 2007; Chojnicka, 2001; Arvers, Choquet, 1999), including also the research by the author of this work (Przybysz-Zaremba, 2006) - the problem of the alcohol abuse and the aggression / violence are strictly integrated with each other.

Conducting the research for the needs of this work, the author has checked the relations between men's age (that is sampled women's husbands / partners) and their alcohol abuse. The used statistical analysis confirmed the assumed dependence accepting at the same time the alternative hypothesis $\left(\mathrm{Chi}^{2}{ }_{\text {emp. }} 122.7>\mathrm{Chi}^{2}{ }_{\text {tab. }} 7,78, \mathrm{df}=3, \mathrm{a}=0,05, \mathrm{~V}\right.$-Cramer coefficient $=0.416$ ). The received data confirmed that the aggressive/violent behaviours are strictly integrated with the alcohol abuse. As is results from the data presented in fig. 1, aggression and/or violence happened most often in the sampled families where the men were in their mid- and late-twenties (23-30) and in the same age group there was the highest rate (59.2 \%) of the alcohol abuse (fig. 2.)

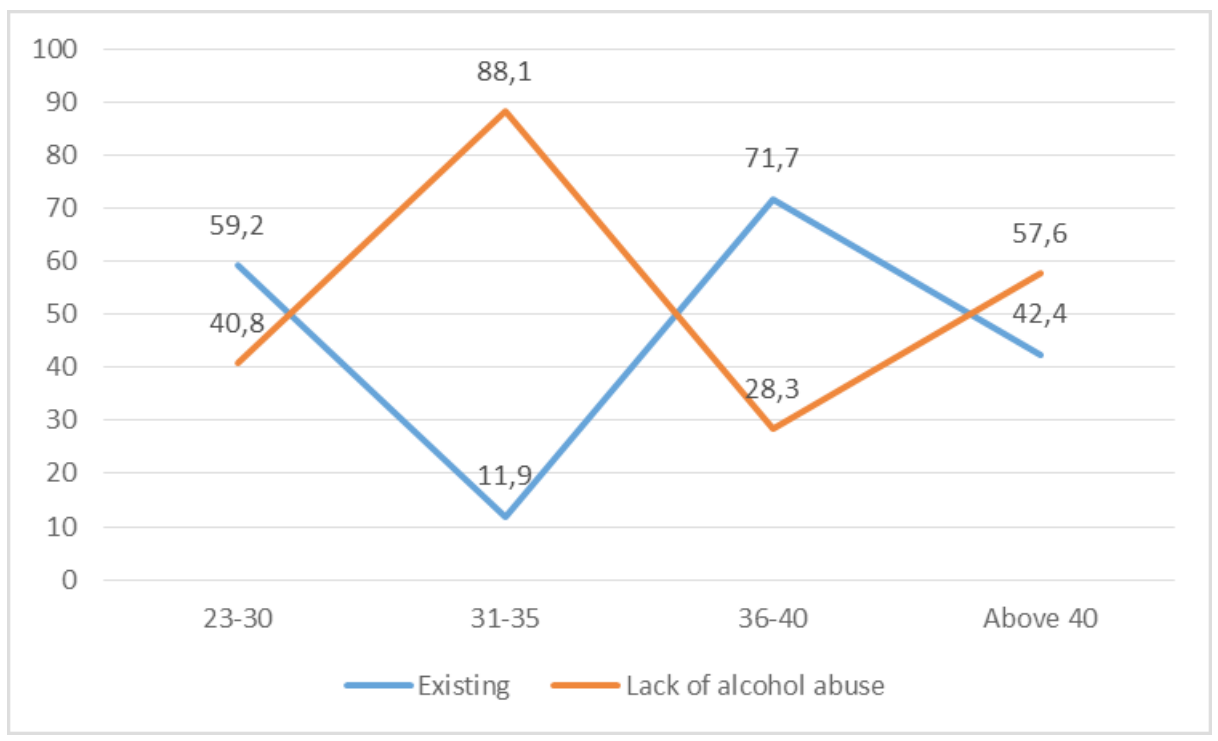

Fig. 2. Men's age and the alcohol abuse (in \%) Source: author's own based on the conducted research 
Alcohol is also abused by the group of men in the age group 36-40 years of age. The rate is at the level of $70 \%$. More than $40 \%$ of men above 40 years of age reach for alcohol ans as it results from the data in fig. 1 there is a very similar result of aggression / violence in family. Thus, it can be supposed that the men in this age group display aggression / violence against their closest ones.

Men's education and the aggressive behaviours and / or violent behaviours and the alcohol abuse in family

The statistical analysis indicated the dependence between men's education and the problem of aggression and / or violence in family $\left(\mathrm{Chi}^{2}{ }_{\text {emp. }} 40.97>\mathrm{Chi}^{2}{ }_{\text {tab. }} .78, \mathrm{df}=3\right.$, $\mathrm{a}=0.05, \mathrm{~V}$-Cramer coefficient $=0.240$ ).

The data included in fig. 3 present that the aggressive and/or violent behaviours are more frequent in families in which the men have the secondary education $(54.4 \%)$ and higher (41.5\%), more seldom with primary education (37.6 \%) and vocational (25.1\%.)

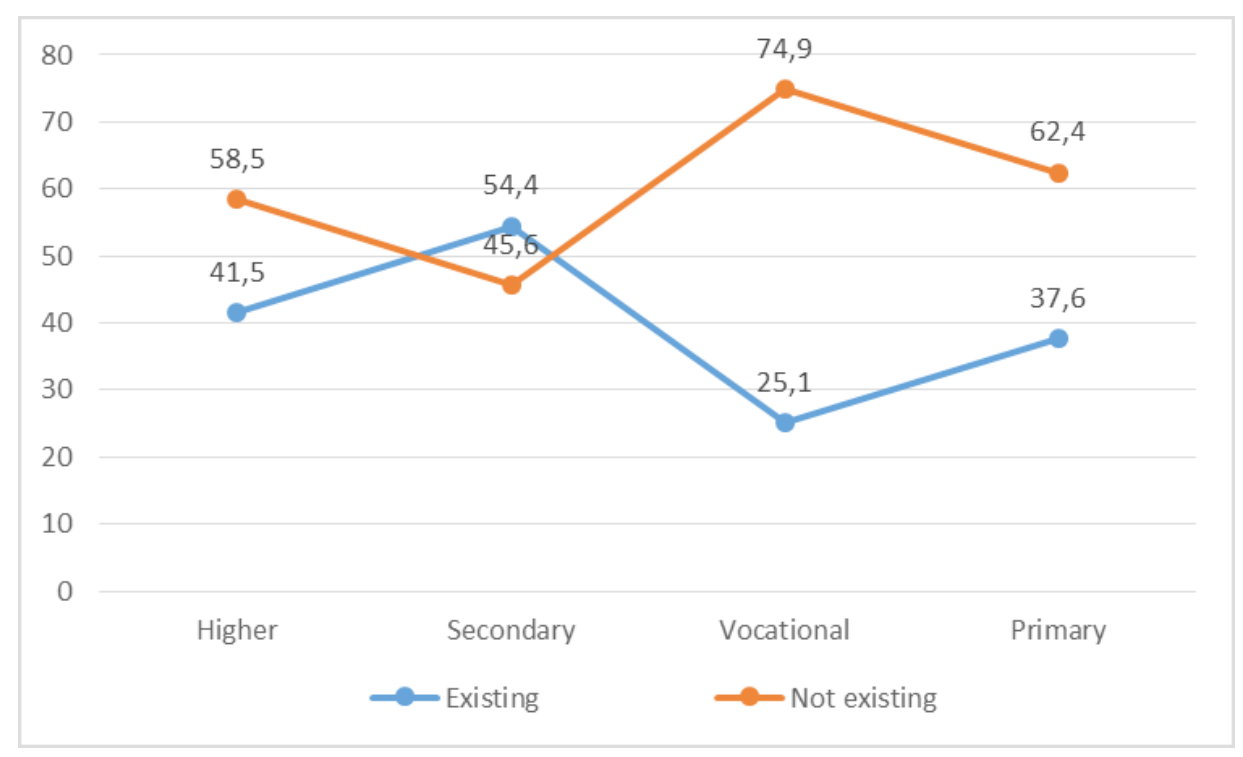

Fig. 3. Men's education and aggression and / or violence in family (in \%) Source: author's own based on the conducted research.

The research also attempted at checking whether men's education as women's life partners having the influence on the aggression and / or violence in family is related to the alcohol abuse. And also in this case the statistical analysis confirmed that the aggression and / or violence in the sampled families are rooted in the men's abuse of alcohol. The accepted alternative hypothesis in the statistical analysis confirmed the dependence 
between men's education and their abuse of alcohol $\left(\mathrm{Chi}^{2}{ }_{\text {emp. }} 119.33>\mathrm{Chi}_{\text {tab. }}{ }^{2} .78, \mathrm{df}=3\right.$, $\mathrm{a}=0.05$, V-Cramer coefficient $=0.410$ ). As it results from the data included in fig. 3 , the problem of aggression and/or violence was most often in sampled families in which the men had higher and secondary education - men with such education also abused alcohol more frequently. The rates for the men's group with secondary education related to aggression and / or violence and the alcohol abuse are very similar and they are both at the level of $50 \%$. In case of the group of men with higher education the rate of alcohol abuse is much higher and it is at the level exceeding $70 \%$ (fig. 4).

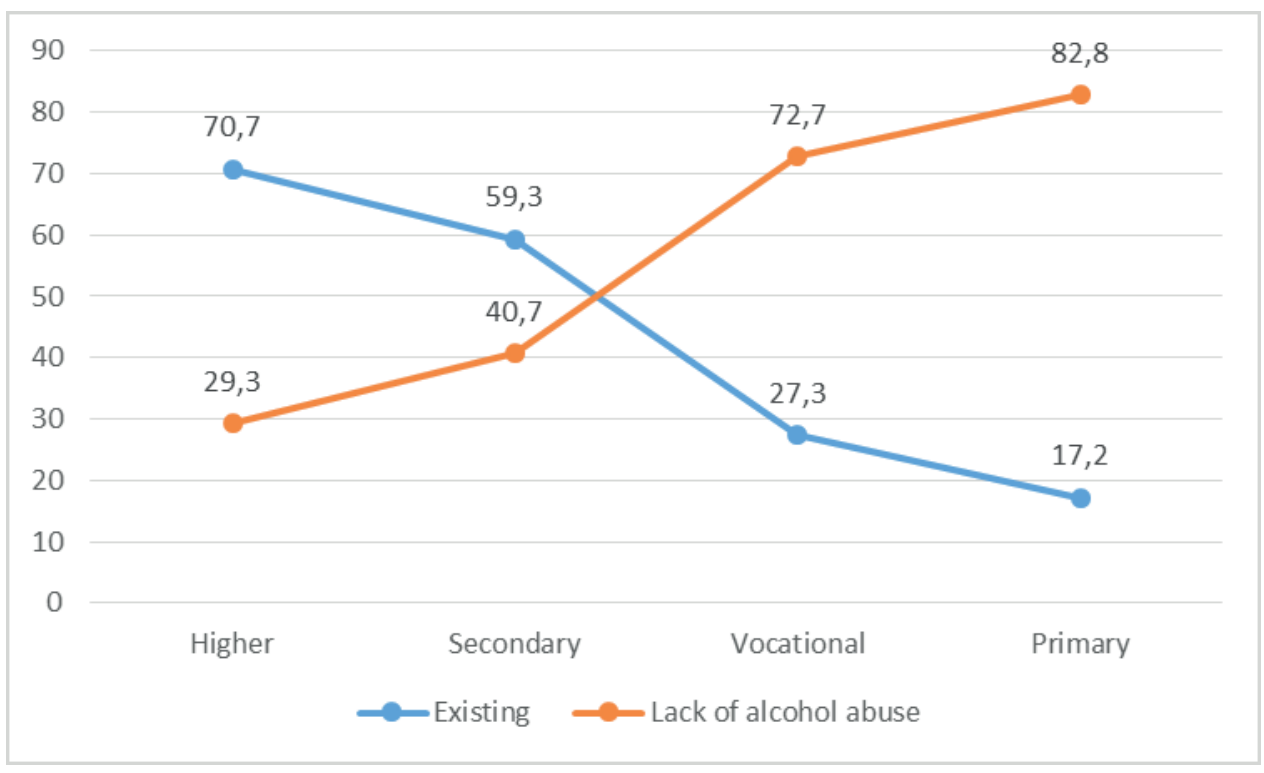

Fig. 4. Men's education and the alcohol abuse (in \%)

Source: author's own based on the conducted research

Analysing data included in the fig. 3 and 4 it was noticed that the men with primary education displayed the aggressive-violent behaviours more often, but they reached for alcohol much more seldom (17.2 \%).

Place of residence and the aggressive behaviours and/or the violent behaviours and the alcohol abuse in family

The assumed alternative hypothesis in the statistical analysis indicated the dependence between the place of residence and the aggressive behaviours and / or the violent behaviours in the sampled families $\left(\mathrm{Chi}^{2}{ }_{\text {emp. }} 57.89>\mathrm{Chi}^{2}{ }_{\text {tab. }} .78, \mathrm{df}=3, \mathrm{a}=0.05, \mathrm{~V}\right.$-Cramer coefficient $=0.286$.) It was observed that the aggressive behaviours and / or the violent behaviours are more frequent in the rural areas than in towns. The highest rate was not- 
ed in the sampled group living in a village of population not exceeding $500(63 \%)$ and slightly more than 500 (41.9\%) (fig. 5.) The data can be explained with the lack of jobs in these areas. During the research the unemployment rate in Warmian-Masurian Province was at the level of $20 \%$ and it Pomeranian Province the unemployment was $17 \%$ while for the whole country this rate was $12.4 \%$. A justification can be definitely higher than in the city problem of alcohol abuse having the influence of existing aggression and / or violence in family.

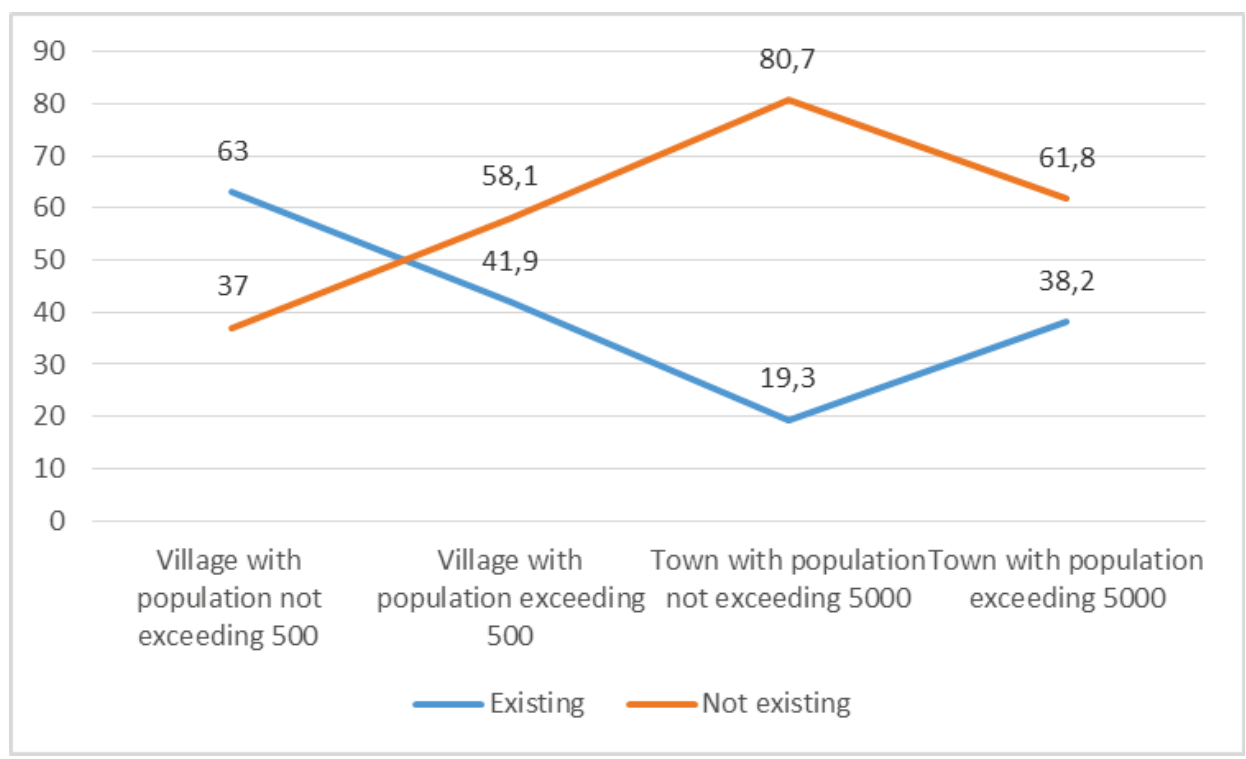

Fig. 5. Place of residence and aggression and / or violence in family (in \%)

Source: author's own based on the conducted research

The lowest rate was noted among the sampled living in (small) towns with the population lower than 5000 (19.3\%).

The statistical analysis also confirmed the dependence between the place of residence and the problem of alcohol abuse in family $\left(\mathrm{Chi}^{2}{ }_{\text {emp. }} 88.68>\mathrm{Chi}^{2}{ }_{\text {tab. }} .78, \mathrm{df}=3, \mathrm{a}=0.05\right.$, V-Cramer coefficient $=0.353$.) Similarly, the problem of aggression and/or violence is more frequent in families living in the rural areas (population lower than 500) (fig. 6.) And in this case a conclusion can be drawn that the problem of aggression and/or violence in family is strictly connected with the problem of alcohol abuse.

The statistical analysis did not confirm the dependence between the type of the job the men perform and the aggression and/or violence in family, but it confirmed the relation between the type of the job the men perform and their alcohol abuse - the received data was the following: $\mathrm{Chi}^{2}{ }_{\text {emp. }} 10.50>\mathrm{Chi}^{2}{ }_{\text {tab. }}$ 5.94, $\mathrm{df}=2, \mathrm{a}=0.05, \mathrm{~V}$-Cramer coefficient $=0.122$. 


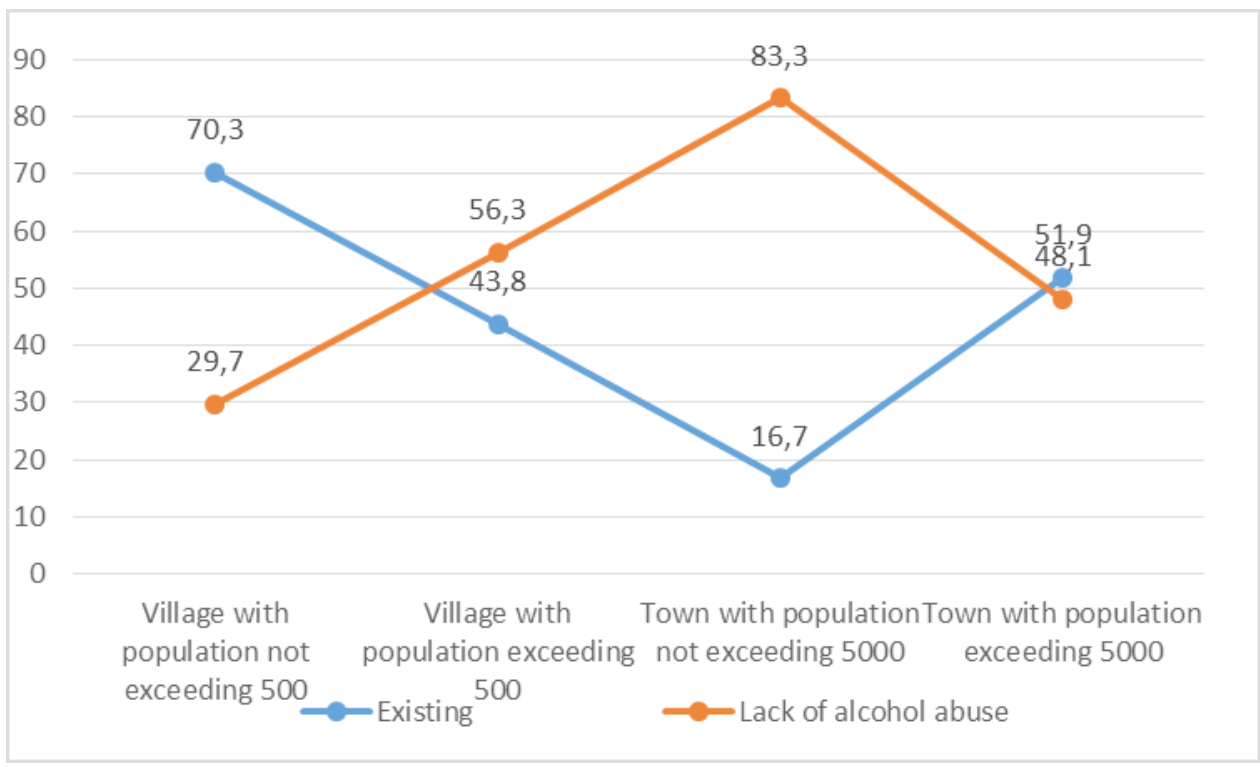

Fig 6. Place of residence and the alcohol abuse (in \%)

Source: author's own based on the conducted research

The type of the job performed by the men and the aggression and / or violence in family and the alcohol abuse

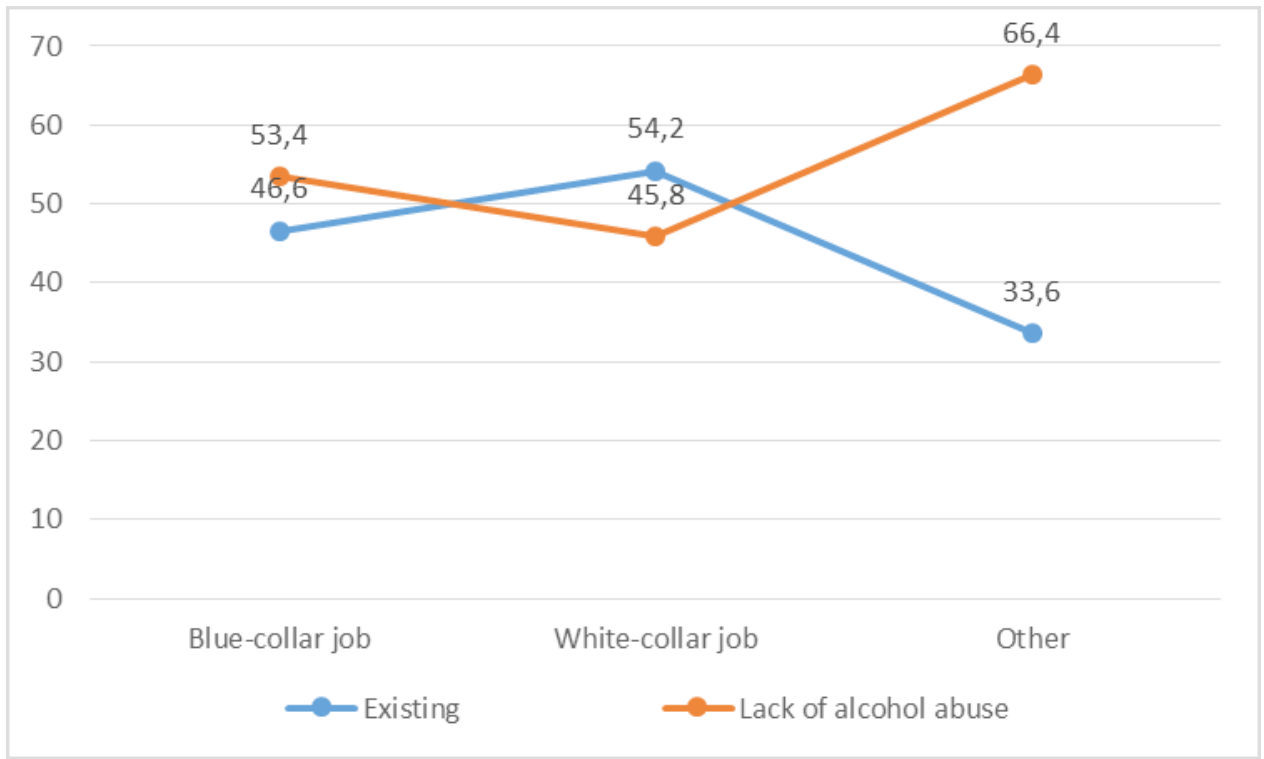

Fig. 7. The type of the job performed by the men and the alcohol abuse (in \%) Source: author's own based on the conducted research 
The data presented in fig. 7 indicate that alcohol is more frequently abused by men doing white-collar jobs (54.2\%) rather than blue-collar jobs (46.6 \%.) In case of the men without the regular job or running their own agricultural farm and/or living on their health benefit - the problem of their alcohol abuse is the least frequent $(66.4 \%$.) At present, the white-collar job belongs to the most stressful ones, which, consequently, can be transferred as men's reaching for alcohol which, to some extent, is treated as means of reducing the stress and tension and which at the same time can trigger the display of aggression and / or violence. It is confirmed, among others, by the data included in fig. 3 which point out that aggression and / or violence is most frequent in women's families whose life partners have higher and secondary education.

\section{Research Conclusions}

The statistical analysis of the empirical material confirms that the displaying of aggression and / or violence is strictly connected with the alcohol abuse. The received data allow for formulating the following conclusions which construct the social and demographic model of the aggressor refuting at the same time the common myth claiming that the aggressor is a person with the lowest education and performing the blue-collar job.

The research indicated that aggression and / or violence:

- are most frequent in families in which men's age is 23-30 years of age. Such men more often reach for alcohol as well. The high rate of alcohol abuse also regards the men of $36-40$ years of age;

- are most often displayed by men with higher and secondary education who also reach for alcohol most frequently;

- most often happen in the rural areas, that is little villages with the population not exceeding 500 and slightly above. Such areas were also noted with the highest rate of men reaching for alcohol;

- the type of the job the man perform did not influence the displays of the aggressive and / or violent behaviours but it had a huge impact on the men reaching for alcohol.

To make a summary of the results of the conducted research, a general social and demographic outline of a contemporary aggressor can be made which is characterised with higher education, doing white-collar job, is until 30 years of age and comes from the rural areas. The model constructed on the basis of the research above does not portray the aggressor fully, as the analysis was made basing only on selected social and demographic factors. However, it presents a young, educated man who living in the globalised world is more frequently unable to handle his own problems without reaching for alcohol and manifests his stress and tension on the closest members of his family. 


\section{References}

Arcimowicz, K. (2005). Męska przemoc, agresja i władza. Niebieska Linia, 5 (40).

Arvers, P., Choquet, M. (1999). Regional variations in alcohol use among young people in France.

Epidemiological approach to alcohol use and abuse by adolescents and conscripts. Drug And Alcohol Dependence, 56 (2), 145-155.

Blackman, J. (1989). Intimate violence. New York, 76.

Burek, M. (2007). Maltretowanie dzieci a alkohol. Raport WHO 2006. Niebieska Linia, 2 (49). Chojnicka, M. (2001). Postępowanie z ofiarami przemocy w rodzinie po reformie administracyjnej kraju. In V. Irons R, Schneider JP. (1997). When is domestic violence a hidden face of addiction? Journal Psychoactive Drugs 1997, 29, 337, p. 44-99.

Jaszczak-Kuźmińska, D., Michalska, K. (2010). Przemoc w rodzinie. In D. Jaszczak-Kuźmińska, K. Michalska (Red.). Przemoc w rodzinie wobec osób starszych i niepełnosprawnych. Poradnik dla pracowników pierwszego kontaktu (pp. 9-10). Warszawa: Ministerstwo Pracy i Polityki Społecznej.

Kaufman, M. (1994). The construction of masculinity and the triad of men's violence. In M. S. Kimmel, M. A. Messner (Red.). Men's lives. Boston: Allyn and Bacon.

Kelder, L. R., McNamara, J. R., Carlson, B., Lynn, S. J. (1991). Perceptions of physical punishment. The relation to childhood and adolescent experiences. Journal of Interpersonal Violence, 6, 432-445. Kimmel, M. S. (2000). The gender society. New York: Oxford University Press. In Kwiatkowska-

Darul (Red.). Przemoc w rodzinie i w szkole. Materiały z sesji naukowej (pp. 89-99). Toruń 5 kwietnia 2001r., Wydawnictwo UMK, Toruń 2001.

Mazur, J. (2002). Przemoc $w$ rodzinie. Teoria i rzeczywistość. Warszawa: Wydawnictwo Akademickie Żak, 13.

Mellibruda, J. (2005). Charakterystyka zjawiska przemocy $w$ rodzinie. Warszawa.

Pospiszyl, I. (1994). Przemoc w rodzinie. Warszawa: WSiP.

Przybysz-Zaremba, M. (2006). Patologie rodziny współczesnej. In W. Muszyński, E. Sikora (Red.).

Małżeństwo i rodzina w ponowoczesności. Szanse-zagrożenia-patologie (pp. 297-305). Toruń: Wydawnictwo Adam Marszałek.

Przybysz-Zaremba, M. (2013). Das Problem der Aggression und Gewalt in polnischen

Gymnasien - Vorbeugendes Verfahren. In M. Marchwacka (Red.). Gesundheitsförderung im Setting Schule (p. 275). Wiesbaden: Wydawnictwo "Springer".

Sasal, H. D. (1998). Niebieskie karty. Warszawa: PARPA, p. 17.

Więckiewicz, B. (2012). Rodzina polska w obliczu kryzysu gospodarczego. In M. Klimek, B. Więckiewicz (Red.). Problemy współczesnej rodziny polskiej (pp. 73-87). Lublin: Wydawnictwo KUL.

Więckiewicz, B. (2013). Wprowadzenie. In B. Więckiewicz (Red.). Rodzina polska - nowe wyzwania. Wybrane aspekty (pp. 7-13). Stalowa Wola: WZNoS.

World Health Organization. (2002). World report of violence and health. Bruksela.

Zimbardo, P. G., Gerrig, R. J. (2011). Psychologia i życie. Warszawa: Wydawnictwo Naukowe PWN, 346. 


\title{
Legislative acts
}

J.o.L. of 2010, no. 125 pos. 842 .

J.o.L. No. 88 , pos. 553 , with later amendments

\section{Socialiniai ir demografiniai veiksniai, lemiantys agresijos ir smurto šeimoje apraiškas: agresoriaus modelio konstravimas}

\author{
Małgorzata Przybysz-Zaremba ${ }^{1}$, Agata Katkoniené ${ }^{2}$
}

1 Pultusko humanitarinių mokslų akademija, Pedagogikos fakultetas, 36B Mickiewicza St., 06-100 Pułtusk, Lenkija, malgorzata.p_z@interia.pl

2 Mykolo Romerio universitetas, Socialinės politikos fakultetas, Socialinio darbo katedra, Ateities g. 20, 08303 Vilnius, agata.katkoniene@mruni.eu

\section{Santrauka}

Straipsnyje analizuojami socialiniai-demografiniai agresijos ir smurto šeimoje veiksniai. Dabartiniai agresijos ir smurto šeimoje moksliniai tyrimai rodo, kad svarbus tokio elgesio veiksnys yra piktnaudžiavimas alkoholiu.

Pateikto tyrimo tikslas - ištirti pasirinktus socialinius-demografinius veiksnius, kurie gali turèti įtakos agresijos, smurto ir prievartos apraiškoms bei piktnaudžiavimui alkoholiu. Remiantis moksline literatūra galima teigti, kad agresija ir smurtas dažniausiai užfiksuojami pavartojus alkoholio. Tyrime analizuojami tokie veiksniai: vyrų amžius, išsilavinimas, gyvenamoji vieta ir darbo pobūdis. Tyrime dalyvavo 710 moterų. Moterys buvo iš dviejų vaivadijų: Varmijos Mozūrų ir Pamario, esančių Šiaurès Lenkijoje. Duomenų apdorojimui buvo naudojama statistinè analizė, panaudotas Chi kvadrato testas ir Kramerio $\mathrm{V}_{\mathrm{xy}}$ koeficientas.

Rezultatų analizė patvirtino, kad agresijos ir smurto apraiškos yra glaudžiai susijusios su alkoholio vartojimu. Tyrimai parodè, kad agresija ir smurtas dažniausiai pasireiškia šeimose, kur vyrų amžius 23-30 metų; pasireiškia tarp turinčių aukštesnịjị ir vidurinị išsilavinimą, kurie dažnai vartoja alkoholị bei didžiausias paplitimas yra kaimo vietovėse. Tyrimai nepatvirtino ryšio tarp vyrų atliekamo darbo bei agresijos ir smurto apraiškų. Tyrimas leidžia daryti bendrą sociologinị-demografinị šiuolaikinio agresoriaus modelio eskizą, kuriam yra būdinga: aukštesnysis išsilavinimas, 30 metų ir jaunesnis amžius bei gyvenimas kaimo vietovejje.

Esminiai žodžiai: agresija, prievarta, piktnaudžiavimas alkoholiu, šeima. 